Original Research Paper

\title{
Nodulation and Biomass Yield Response of Cowpea to Row Spacing and Phosphorus Fertilizer Application in the Guinea Savanna Agro-Ecological Zone of Ghana
}

\author{
${ }^{1}$ Alhassan Bawa and ${ }^{2}$ Lukman Yussif \\ ${ }^{I}$ Department of Agronomy, Faculty of Agriculture, University for Development Studies, Tamale, Ghana \\ ${ }^{2}$ Community Life Improvement Programme, Tamale, Ghana
}

Article history

Received: 24-10-2016

Revised: $13-07-2017$

Accepted: 23-12-2017

Corresponding Author: Alhassan Bawa

Department of Agronomy,

Faculty of Agriculture,

University for Development

Studies, Tamale, Ghana

Tel. +233243483821

Email: abawai1@yahoo.com

\begin{abstract}
Phosphorus fertilizer application and planting distance play a major role in the production of shoot, root and nodule dry biomass of cowpea. However, phosphorus is a major limiting nutrient in soils in Ghana. Selection of cowpea varieties that produce good biomass yield under low soil phosphorus or those with high phosphorus response efficiency can be a low input approach in solving this problem in Ghana. Two-season experiments were conducted to evaluate the influence of phosphorus (P) fertilizer and row spacing on growth, nodulation and biomass yield in cowpea. Each of the two experiments comprised of 16 treatment combinations of 4 cowpea varieties, 2 levels of row spacing and 2 levels of $\mathrm{P}_{2} \mathrm{O}_{5}$ application laid out in a $4 \times 2 \times 2$ factorial experiments in RCBD with four replications. The cowpea varieties were IT $\times$ P 148, Valenga, Bengkpla and DPC. The levels of row spacing were $60 \times 20 \mathrm{~cm}$ and $40 \times 20 \mathrm{~cm}$, whilst the levels of $P$ were 0 and $30 \mathrm{~kg} \mathrm{ha}^{-1}$ $\mathrm{P}_{2} \mathrm{O}_{5}$. The study revealed that varieties DPC and Valenga performed relatively better with respect to shoot and root dry biomass production, number of nodules produced and nodule dry biomass production across both levels of row spacing and phosphorus fertilizer application. The study further established that row spacing of $60 \times 40 \mathrm{~cm}$ and $\mathrm{P}$ level of $30 \mathrm{~kg} \mathrm{ha}^{-1}$ also produced significantly higher quantities of shoot and root dry biomass, number of nodules and nodule dry biomass as compared to row spacing of $40 \times 20 \mathrm{~cm}$ and $\mathrm{P}$ level of $0 \mathrm{~kg} \mathrm{ha}^{-1}$. For the purpose of producing leguminous fodder crops for feeding livestock, varieties DPC and Valenga should be cultivated for improved animal nutrition. Row spacing of $60 \times 40$ $\mathrm{cm}$ and phosphorus fertilizer application level of $30 \mathrm{~kg} \mathrm{ha}^{-1}$ should also be used for increased biomass yield.
\end{abstract}

Keywords: Cowpea, Nodulation, Biomass Yield, Row Spacing, Phosphorus Fertilizer, Ghana

\section{Introduction}

Cowpea (Vigna unguiculata L. Walp) is the most important legume in Ghana. The bulk of production occurs in the savanna regions of Northern Ghana, although cowpea can be grown in all ecological zones of Ghana. Cowpea production has gained attention in most farming systems in developing countries due to the significant role the crop plays in meeting the protein needs of farm animals and most farm households. The crop is an important source of food, income and livestock feed and forms a major component of tropical farming systems because of its ability to improve marginal lands through nitrogen fixation and as cover crop (Sanginga et al., 2000). Cowpea is widely cultivated in Ghana under rain-fed conditions mainly in the savanna and transitional agro-ecological zones (CRI, 2006). The seed and biomass yield of cowpea in Africa, particularly Ghana, is estimated to be $45 \%$ of that of the developed countries (IITA, 2003). Among the factors responsible for such low yield are phosphorus (P) deficiency and inappropriate plant spacing for cowpea production (IITA, 2003). The phosphorus deficiency occurs as a result of either inherent low levels of phosphorus in the soils or depletion of the nutrient through cultivation. Ahenkorah (1967) reported that 
Ghanaian soils are generally low in available phosphorus and this may be partly attributed to the high phosphorus retention capacity of the soils and partly to the large proportion of phosphorus which exist in the organic form (Acquaye, 1968).

Phosphorus (P) is one of the most essential elements for crop production in many tropical soils. However, many tropical soils are inherently deficient in $\mathrm{P}$ (Osodeke, 2005) and nitrogen (Haruna and Aliyu, 2011). The deficiency can be so acute in some soils of the Savanna zone of Western Africa resulting in cessation of plant growth as soon as the $\mathrm{P}$ stored in the seed is exhausted (Mokwunye and Bationo, 2002). Cowpea does not require too much nitrogen fertilizer because it fixes its own nitrogen from the air using the nodules in its roots. However, in areas where soils are poor in nitrogen, there is a need to apply a small quantity of about $15 \mathrm{~kg}$ of nitrogen as a starter dose for a good crop. Cowpea requires more phosphorus than nitrogen in the form of single super phosphate or SUPA (Nkaa et al., 2014).

Phosphorus plays a key role in many plant processes such as energy metabolism, nitrogen fixation, synthesis of nucleic acids and membranes, photosynthesis, respiration and enzyme regulation. Phosphorus is critical to cowpea yield because it is reported to stimulate growth, initiate nodule formation as well as influence the efficiency of the rhizobium legume symbiosis (Nkaa et al., 2014). It is required in large quantities in young cells such as shoot and root tips to increase metabolism and promote rapid cell division. It also aids in flower initiation, seed and fruit development (Ndakidemi and Dakora, 2007). According to Oti et al. (2004), phosphorus decreases zinc concentration in the cowpea grain, thereby affecting its nutritional quality. It is required for the physiological processes of protein synthesis and energy transfer in plants (Nkaa et al., 2014). Application of phosphorus has been reported by several authors to improve yield and shoot and root dry biomass of cowpea.

Cowpea is mainly produced by small scale farmers who constitute the bulk of the country's farming population. These farmers plant cowpea as an intercrop and therefore do not follow specific spacing procedure, as they rely on the spacing of the major crop. Even though the soils are low in phosphorus, cowpea farmers in Northern Ghana do not apply phosphorus. A study conducted by Sharma and Paliwal (1973) recommended $40 \mathrm{~kg} \mathrm{ha}^{-1}$ of $\mathrm{P}_{2} \mathrm{O}_{5}$ application and concluded that seed rate depended on the plant type and seed size.

The various row spacing and phosphorus applications rate recommended had not given the best results in terms of nodulation and shoot and root dry biomass yield. This study was therefore conducted to determine the appropriate levels of row spacing and phosphorus fertilizer application for improved nodulation and biomass yield of four cowpea varieties.

\section{Materials and Methods}

\section{Land Preparation}

The experiments were conducted at the experimental field of the Savanna Agricultural Research Institute (SARI) at Nyankpala during the 2014 and 2015 cropping seasons. The study area lies between latitude $9^{\circ} 25^{1} \mathrm{~N}$ and Longitude $0^{\circ} 58^{1} \mathrm{~W}$ and it is $183 \mathrm{~m}$ above sea level. The field was ploughed and debris removed. The field was then demarcated using lines and pegs and leveled using a hoe before seeds of the four genotypes were planted.

\section{Experimental Design}

The design used was split plot design. The treatments combination was factorial RCBD with four replications. In all, three factors were considered in the two-season experiments. The first factor was four cowpea cultivars. The second factor was row spacing while the third factor was phosphorus application. The cowpea cultivars were the main plot treatment, row spacing was the sub plot treatment and phosphorus application was the sub - sub plot treatment. The experiments comprised of 16 treatment combinations of 4 cowpea varieties, 2 levels of row spacing and 2 levels of Phosphorus $(\mathrm{P})$ fertilizer. The cowpea varieties were IT $\times$ P 148, Valenga, Bengkpla and Dual Purpose Cowpea (DPC). The levels of row spacing were $40 \times 20$ and $60 \times 40 \mathrm{~cm}$, whilst the $P$ fertilizer levels were 0 (control) and $30 \mathrm{~kg} \mathrm{ha}^{-1} \mathrm{P}_{2} \mathrm{O}_{5}$. A total of 64 plots were used, each plot measuring $3 \times 5 \mathrm{~m}$. Blocks were separated from one another by a $2 \mathrm{~m}$ alley, whilst replications within a block were separated by a $1 \mathrm{~m}$ alley. Plots within a replication were separated by $0.5 \mathrm{~m}$ alley.

Seeds of cowpea were obtained from the gene bank at the CSIR-Savanna Agricultural Research Institute (CSIR-SARI), Nyankpala. Three seeds were planted per hill but were later thinned to two plants per hill 2 weeks after planting at a density of 240 plants per plot corresponding to 166,666 plants $\mathrm{ha}^{-1}$. This study was conducted at the CSIR-SARI experimental field from July to September during the 2014 and 2015 cropping seasons. The crops were mainly rain fed.

\section{Cultural Practices}

Manual weeding was done immediately after germination. Urea was applied as a basal fertilizer at $62.6 \mathrm{~kg} \mathrm{ha}^{-1}$ by side placement method two Weeks After Planting (WAP). The field was weeded again at 5 WAP. The chemical karate was sprayed at 6,7 and 9 WAP to control insect pests. All agronomic practices were carried out accordingly.

\section{Data Collection and Statistical Analysis}

Data was collected on the following parameters at the flowering stage: Nodule number, nodule dry biomass, shoot dry biomass and root dry biomass. 
The tagged plants were uprooted with the help of a dibber and the root system washed gently in clean water. The nodules were then separated and counted per plant. Nodule counting was done at 9 WAP. Nodules per plot were kept in labeled envelops and oven dried at $80^{\circ} \mathrm{C}$ for $48 \mathrm{~h}$. Average dry biomass of nodules per plant was computed and expressed in grams and later extrapolated to kilograms per hectare. The cowpea shoot and root dry biomass were also determined by arranging the shoot and root in separate envelopes and drying them in the calibrated oven at a temperature of $80^{\circ} \mathrm{C}$ for $48 \mathrm{~h}$ as already explained in the case of nodule dry biomass. The data collected were subjected to Analysis of Variance (ANOVA) using Genstat statistical package and where the F-values were found to be significant, the treatment means were separated by Least Significant Difference (LSD) at 5\% level of probability.

\section{Results}

\section{Shoot Dry Biomass}

When varieties were planted at a row spacing of $40 \times 20 \mathrm{~cm}$, the variety DPC recorded the highest shoot dry biomass of $569.64 \mathrm{~kg} \mathrm{ha}^{-1}$, while IT $\times \mathrm{P} 148$ recorded the lowest shoot dry biomass of $297.18 \mathrm{~kg} \mathrm{ha}^{-1}$ (Table 1). The variety DPC was significantly different $(p<0.05)$ from Valenga and IT $\times$ P 148. At plant spacing of $60 \times 40 \mathrm{~cm}$, variety IT $\times \mathrm{P} 148$ recorded a maximum shoot dry biomass of $1114.01 \mathrm{~kg} \mathrm{ha}^{-1}$, while Bengkpla recorded a minimum shoot dry biomass of $843.54 \mathrm{~kg}$ $\mathrm{ha}^{-1}$. The variety IT $\times \mathrm{P} 148$ was not significantly different $(p>0.05)$ from DPC and Valenga.
At Phosphorus (P) fertilizer application level of $0 \mathrm{~kg}$ $\mathrm{ha}^{-1}$, genotype IT $\times \mathrm{P} 148$ recorded the highest of $666.97 \mathrm{~kg}$ $\mathrm{ha}^{-1}$ of shoot dry biomass, whilst Bengkpla recorded the lowest of $599.06 \mathrm{~kg} \mathrm{ha}^{-1}$. However, all the four varieties were not significantly different $(\mathrm{p}>0.05)$ (Table 1$)$. At $\mathrm{P}$ level of $30 \mathrm{~kg} \mathrm{ha}^{-1}$, DPC recorded the highest shoot dry biomass of $1008.54 \mathrm{~kg} \mathrm{ha}^{-1}$, whilst Bengkpla recorded the lowest of $687.44 \mathrm{~kg} \mathrm{ha}^{-1}$. The genotype DPC was significantly different $(\mathrm{p}<0.05)$ from Bengkpla.

\section{Root Dry Biomass}

The study established that at phosphorus (P) fertilizer application level of $0 \mathrm{~kg} \mathrm{ha}^{-1}$, Bengkpla recorded the maximum root dry biomass of $112.93 \mathrm{~kg} \mathrm{ha}^{-1}$, while IT $\times$ P 148 recorded the minimum root dry biomass $(61.73 \mathrm{~kg}$ $\mathrm{ha}^{-1}$ ) (Table 2). There were however, no significant differences $(\mathrm{p}<0.05)$ among the four cowpea varieties for root dry biomass production. At $30 \mathrm{~kg} \mathrm{ha}^{-1} \mathrm{P}$ level, IT $\times$ P 148 recorded the lowest root dry biomass yield (69.58 $\mathrm{kg} \mathrm{ha}^{-1}$ ) whilst Bengkpla produced the highest root dry biomass of $132.52 \mathrm{~kg} \mathrm{ha}^{-1}$. Bengkpla was significantly different $(p<0.05)$ from IT $\times$ P 148 in terms of root dry biomass production.

When plant spacing was $40 \times 20 \mathrm{~cm}$, Bengkpla recorded the highest root dry biomass of $74.92 \mathrm{~kg} \mathrm{ha}^{-1}$ while IT $\times \mathrm{P}$ 148 recorded the least of $24.25 \mathrm{~kg} \mathrm{ha}^{-1}$ (Table 2). The variety Bengkpla yielded the highest root dry biomass of $170.53 \mathrm{~kg} \mathrm{ha}^{-1}$ at a row spacing of $60 \times 40 \mathrm{~cm}$, whilst IT $\times$ P 148 produced the lowest root dry biomass yield of $107.05 \mathrm{~kg} \mathrm{ha}^{-1}$. The variety Bengkpla was statistically different $(\mathrm{p}<0.05)$ from IT $\times$ P 148 and DPC.

Table 1: Variation of phosphorus (P) fertilizer application and row spacing on shoot dry biomass yield of cowpea during field screening in 2014 and 2015 cropping seasons

\begin{tabular}{|c|c|c|c|c|}
\hline \multirow[b]{2}{*}{ Cultivar } & \multicolumn{2}{|c|}{ Shoot dry biomass $\left(\mathrm{kg} \mathrm{ha}^{-1}\right)$} & \multicolumn{2}{|c|}{ Shoot dry biomass $\left(\mathrm{kg} \mathrm{ha}^{-1}\right)$} \\
\hline & $\mathrm{P}$ at $0 \mathrm{~kg} \mathrm{ha}^{-1}$ & $\mathrm{P}$ at $30 \mathrm{~kg} \mathrm{ha}^{-1}$ & $40 \times 20 \mathrm{~cm}$ & $60 \times 40 \mathrm{~cm}$ \\
\hline $\mathrm{IT} \times \mathrm{P} 148$ & 666.97 & 744.23 & 297.18 & 1114.01 \\
\hline Bengkpla & 599.06 & 687.44 & 442.95 & 843.54 \\
\hline Valenga & 613.10 & 737.37 & 328.05 & 1022.43 \\
\hline $\mathrm{DPC}$ & 604.10 & 1008.54 & 569.64 & 1043.01 \\
\hline Mean & 620.81 & 794.40 & 409.46 & 1005.75 \\
\hline LSD (0.05) & 206.10 & 316.10 & 211.10 & 217.10 \\
\hline
\end{tabular}

LSD means Least Significant Difference

Table 2: Variation of phosphorus $(\mathrm{P})$ fertilizer application and row spacing on root dry biomass yield of cowpea during field screening

\begin{tabular}{|c|c|c|c|c|}
\hline \multirow[b]{2}{*}{ Cultivar } & \multicolumn{2}{|c|}{ Root dry biomass $\left(\mathrm{kg} \mathrm{ha}^{-1}\right)$} & \multicolumn{2}{|c|}{ Root dry biomass $\left(\mathrm{kg} \mathrm{ha}^{-1}\right)$} \\
\hline & $\mathrm{P}$ at $0 \mathrm{~kg} \mathrm{ha}^{-1}$ & $\mathrm{P}$ at $30 \mathrm{~kg} \mathrm{ha}^{-1}$ & $40 \times 20 \mathrm{~cm}$ & $60 \times 40 \mathrm{~cm}$ \\
\hline $\mathrm{IT} \times \mathrm{P} 148$ & 61.73 & 69.58 & 24.25 & 107.05 \\
\hline Bengkpla & 112.93 & 132.52 & 74.92 & 170.53 \\
\hline Valenga & 64.96 & 88.15 & 33.08 & 120.03 \\
\hline $\mathrm{DPC}$ & 68.32 & 85.32 & 44.69 & 108.67 \\
\hline Mean & 76.99 & 93.89 & 44.24 & 126.57 \\
\hline $\operatorname{LSD}(0.05)$ & 54.89 & 54.89 & 44.81 & 54.90 \\
\hline
\end{tabular}

LSD means Least Significant Difference 
Table 3: Effect of phosphorus (P) fertilizer application and row spacing on nodule number of cowpea during field screening in 2014 and 2015 cropping seasons

\begin{tabular}{|c|c|c|c|c|}
\hline \multirow[b]{2}{*}{ Cultivar } & \multicolumn{2}{|c|}{ Nodule number } & \multicolumn{2}{|c|}{ Nodule number } \\
\hline & $\mathrm{P}$ at $0 \mathrm{~kg} \mathrm{ha}^{-1}$ & $\mathrm{P}$ at $30 \mathrm{~kg} \mathrm{ha}^{-1}$ & $40 \times 20 \mathrm{~cm}$ & $60 \times 40 \mathrm{~cm}$ \\
\hline $\mathrm{IT} \times \mathrm{P} 148$ & 41.00 & 58.00 & 49.00 & 53.00 \\
\hline Bengkpla & 35.00 & 80.00 & 58.00 & 73.00 \\
\hline Valenga & 44.00 & 88.00 & 66.00 & 80.00 \\
\hline $\mathrm{DPC}$ & 62.00 & 76.00 & 69.00 & 77.00 \\
\hline Mean & 46.00 & 76.00 & 61.00 & 71.00 \\
\hline $\operatorname{LSD}(0.05)$ & 18.33 & 29.33 & 17.49 & 17.33 \\
\hline
\end{tabular}

LSD means Least Significant Difference

Table 4: Effect of phosphorus (P) fertilizer application and row spacing on nodule dry biomass yield of cowpea during field screening

\begin{tabular}{|c|c|c|c|c|}
\hline \multirow[b]{2}{*}{ Cultivar } & \multicolumn{2}{|c|}{ Nodule dry biomass $\left(\mathrm{kg} \mathrm{ha}^{-1}\right)$} & \multicolumn{2}{|c|}{ Nodule dry biomass $\left(\mathrm{kg} \mathrm{ha}^{-1}\right)$} \\
\hline & $\mathrm{P}$ at $0 \mathrm{~kg} \mathrm{ha}^{-1}$ & $\mathrm{P}$ at $30 \mathrm{~kg} \mathrm{ha}^{-1}$ & $40 \times 20 \mathrm{~cm}$ & $60 \times 40 \mathrm{~cm}$ \\
\hline $\mathrm{IT} \times \mathrm{P} 148$ & 23.13 & 40.63 & 31.38 & 34.60 \\
\hline Bengkpla & 17.25 & 62.25 & 39.75 & 55.24 \\
\hline Valenga & 26.00 & 70.00 & 48.00 & 62.05 \\
\hline DPC & 44.00 & 57.88 & 50.94 & 58.80 \\
\hline Mean & 27.60 & 57.69 & 42.52 & 52.67 \\
\hline $\operatorname{LSD}(0.05)$ & 7.33 & 10.33 & 9.49 & 8.33 \\
\hline
\end{tabular}

LSD means Least Significant Difference

\section{Nodule Number}

The study revealed that at phosphorus fertilizer application level of $0 \mathrm{~kg} \mathrm{ha}^{-1}$, DPC recorded the highest number of nodules (62), while Bengkpla recorded the lowest of 35 nodules (Table 3 ). Variety DPC significantly differed $(\mathrm{p}<0.05)$ from IT $\times$ P 148 and Bengkpla for nodule production. At $30 \mathrm{~kg} \mathrm{ha}^{-1} \mathrm{P}$ level, IT $\times \mathrm{P} 148$ recorded the lowest number of nodules (58) whilst Valenga produced the highest number of nodules of 88 . Valenga was significantly different $(\mathrm{p}<0.05)$ from IT $\times \mathrm{P}$ 148 with respect to nodule production.

When plant spacing was $40 \times 20 \mathrm{~cm}$, DPC produced the highest number of nodule count (69), while IT $\times$ P 148 produced the lowest of 49 nodules (Table 3). DPC was not significantly different $(\mathrm{p}>0.05)$ from Valenga and Bengkpla. At row spacing of $60 \times 40 \mathrm{~cm}$, Valenga produced the highest number of nodules of 80 , while IT $\times$ P 148 recorded the least of 53 nodules. The variety Valenga was statistically different $(\mathrm{p}<0.05)$ from IT $\times$ P 148 .

\section{Nodule Dry Biomass}

When genotypes were planted at a row spacing of $40 \times 20 \mathrm{~cm}$, DPC produced the highest nodule dry biomass yield of $50.94 \mathrm{~kg} \mathrm{ha}{ }^{-1}$, while IT $\times \mathrm{P} 148$ produced the lowest nodule dry biomass yield of 31.38 $\mathrm{kg} \mathrm{ha}^{-1}$ (Table 4). The variety DPC was significantly different $(p<0.05)$ from IT $\times P 148$. At a row spacing of $60 \times 40 \mathrm{~cm}$, variety Valenga recorded the maximum nodule dry biomass of $62.05 \mathrm{~kg} \mathrm{ha}^{-1}$, while IT $\times \mathrm{P} 148$ recorded the minimum nodule dry biomass of $34.60 \mathrm{~kg}$ $\mathrm{ha}^{-1}$. The genotype Valenga was not significantly different ( $p>0.05)$ from DPC and Bengkpla.

The genotype DPC produced the highest nodule dry biomass of $44 \mathrm{~kg} \mathrm{ha}^{-1}$ at phosphorus application level of $0 \mathrm{~kg} \mathrm{ha}^{-1}$, whilst genotype Bengkpla recorded the lowest nodule dry biomass yield of $17.25 \mathrm{~kg} \mathrm{ha}^{-1}$. However, DPC was significantly different $(\mathrm{p}<0.05)$ from Bengkpla, Valenga and IT $\times$ P 148 (Table 4). At P level of $30 \mathrm{~kg}$ $\mathrm{ha}^{-1}$, Valenga recorded the highest nodule dry biomass of $70 \mathrm{~kg} \mathrm{ha}^{-1}$, whilst IT $\times \mathrm{P} 148$ recorded the lowest of $40.63 \mathrm{~kg} \mathrm{ha}^{-1}$ of nodule dry biomass. Valenga was not significantly different ( $\mathrm{p}>0.05$ ) from Bengkpla.

\section{Vegetative Traits}

The effect of two levels of phosphorus (P) fertilizer application was assessed by comparing the parameters measured. The P level of $0 \mathrm{~kg} \mathrm{ha}^{-1}$ significantly reduced all the parameters measured as compared to parameters that received $30 \mathrm{~kg} \mathrm{ha}^{-1}$ of $\mathrm{P}_{2} \mathrm{O}_{5}$ (Table 5). When the parameters measured were compared in terms of percentage reduction, it was realized that the highest percentage reduction of $39.5 \%$ was recorded for number of nodules produced, whilst the lowest of $18.0 \%$ was recorded for root dry biomass production.

The effect of row spacing was also assessed by comparing the parameters measured due to variation in row spacing (Table 6). When the parameters measured were compared due to differential row spacing, it was observed that root dry biomass recorded the highest percentage reduction of $65.1 \%$ due to closer row spacing, whilst nodule dry biomass production recorded the lowest percentage reduction of $14.0 \%$. 
Table 5: Comparing parameters measured at two different levels of phosphorus $(\mathrm{P})$ fertilizer application

\begin{tabular}{|c|c|c|c|c|}
\hline \multirow[b]{2}{*}{ Vegetative trait } & \multicolumn{4}{|l|}{ Treatment } \\
\hline & $\mathrm{P}$ at $30 \mathrm{~kg} \mathrm{ha}^{-1}$ & $\mathrm{P}$ at $0 \mathrm{~kg} \mathrm{ha}^{-1}$ & $\begin{array}{l}\% \text { reduction due } \\
\text { to } \mathrm{P} \text { variation }\end{array}$ & LSD $(0.05)$ \\
\hline Shoot dry biomass $\left(\mathrm{kg} \mathrm{ha}^{-1}\right)$ & $794.40^{\mathrm{a}}$ & $620.81^{b}$ & 21.9 & 201.10 \\
\hline Root dry biomass $\left(\mathrm{kg} \mathrm{ha}^{-1}\right)$ & $93.89^{\mathrm{a}}$ & $76.99^{\mathrm{b}}$ & 18.0 & 14.81 \\
\hline Nodule number & $76.00^{\mathrm{a}}$ & $46.00^{\mathrm{b}}$ & 39.5 & 28.33 \\
\hline Nodule dry biomass $\left(\mathrm{kg} \mathrm{ha}^{-1}\right)$ & $77.69^{\mathrm{a}}$ & $47.60^{\mathrm{b}}$ & 38.7 & 20.33 \\
\hline
\end{tabular}

Traits having different letters (horizontal direction) are significantly different at the 5\% level of probability

Table 6: Comparing parameters measured at two different levels of row spacing

\begin{tabular}{|c|c|c|c|c|}
\hline \multirow[b]{2}{*}{ Vegetative trait } & \multicolumn{2}{|l|}{ Treatment } & \multirow{2}{*}{$\begin{array}{l}\text { \% reduction due } \\
\text { to differential } \\
\text { row spacing }\end{array}$} & \multirow[b]{2}{*}{$\operatorname{LSD}(0.05)$} \\
\hline & $60 \times 40 \mathrm{~cm}$ & $40 \times 20 \mathrm{~cm}$ & & \\
\hline Shoot dry biomass $\left(\mathrm{kg} \mathrm{ha}^{-1}\right)$ & $1005.75^{\mathrm{a}}$ & $409.46^{\mathrm{b}}$ & 59.3 & 301.10 \\
\hline Root dry biomass $\left(\mathrm{kg} \mathrm{ha}^{-1}\right)$ & $126.57^{\mathrm{a}}$ & $44.24^{\mathrm{b}}$ & 65.1 & 34.81 \\
\hline Nodule number & $71.00^{\mathrm{a}}$ & $61.00^{\mathrm{b}}$ & 14.1 & 8.33 \\
\hline Nodule dry biomass $\left(\mathrm{kg} \mathrm{ha}^{-1}\right)$ & $72.67^{\mathrm{a}}$ & $62.52^{\mathrm{b}}$ & 14.0 & 7.30 \\
\hline
\end{tabular}

Traits having different letters (horizontal direction) are significantly different at the 5\% level of probability

\section{Discussion}

\section{Shoot and Root Dry Biomass Production}

Shoot and root dry biomass production was affected by cowpea variety, phosphorus (P) fertilizer application levels and row spacing at various growth stages of the cowpea varieties. The variety Bengkpla consistently recorded the lowest dry shoot biomass yield at the two levels of phosphorus fertilizer application. The genotype DPC produced the highest dry shoot biomass yield across the different levels of $P$. The significant differences $(p<0.05)$ in shoot dry biomass yield among the varieties could be attributed to genetic effect of the individual varieties. Magani and Kuchinda (2009) made similar observation. Ndakidemi and Dakora (2007) also observed that phosphorus is required in large quantities in shoot and root tips development where metabolism is high and cell division is rapid. It is possible that the variety DPC utilized the phosphorus fertilizer judiciously during its growth and development process as compared to Bengkpla. It might be possible that there were over saturation of the phosphorus fertilizer in the soil making the soil nutrients immobile because of inadequate water in the soil and this might have resulted in the relatively low production of shoot dry biomass yield among the variety Bengkpla. Sharma et al. (2002) made a similar observation and reported that over saturation of phosphorus fertilizer in the soil could make the soil nutrients immobile because of inadequate water in the soil. The increased shoot dry biomass production among genotypes DPC and Valenga could be as a result of phosphorus fertilizer application at 30 $\mathrm{kg} \mathrm{ha}{ }^{-1}$. This is because phosphorus fertilization influences robust development of the cowpea cells leading to increased shoot biomass. This is in consonance with the finding of Sharma and Paliwal
(1973) who reported that phosphorus application causes robust overall development of cowpea, resulting in increases of shoot dry weight.

Dry shoot biomass production significantly $(\mathrm{p}<0.05)$ varied among varieties across different levels of row spacing. Variation in row spacing might have caused variation in level of canopy density, leading to variation of photosynthetic rate among genotypes. Fageria et al. (1997) reported that the vegetative growth is greatly influenced by spacing and that the vegetative growth of genotypes supports the photosynthetic capacity of the plants which results in increased yield of shoot and root biomass. They added that closely spaced plants tend to grow taller with less branching, whilst widely spaced plants tend to develop broader branches.

When planting erect/semi-erect type, Fageria et al. (1997) recommended a row spacing of $60 \times 20 \mathrm{~cm}$ with two seeds per hill. They further reported that at this spacing, up to $28 \mathrm{~kg}$ of seeds is required per hectare. Fageria et al. (1997) also reported that local prostrate varieties should be planted at a row spacing of $80 \times 40$ $\mathrm{cm}$, while row spacing of $60 \times 20 \mathrm{~cm}$ and $75 \times 20 \mathrm{~cm}$ respectively, had also been recommended for early and late maturing cowpea varieties, with two plants per hill in each case.

The significant differences in dry root biomass production among varieties could have been due to inherent genetic factors among genotypes. Under closer spacing $(40 \times 20 \mathrm{~cm})$, some genotypes do not get enough space to ensure that their roots develop faster and also broaden out. It is possible that the close spacing might have negatively affected the root dry biomass production of IT $\times$ P 148. This finding contravenes the observation made by Rowland (1993) who reported that plants sown at closer row spacing tend to ensure cool soil temperature through canopy closure while the leaves 
make maximum use of sunlight, thus ensuring higher photosynthetic activity and biomass yield.

There was a significant difference between the control plants that received $0 \mathrm{~kg} \mathrm{ha}{ }^{-1}$ of $\mathrm{P}_{2} \mathrm{O}_{5}$ as compared to the other plants that received $30 \mathrm{~kg} \mathrm{ha}^{-1}$ of phosphorus fertilizer. This could have been due to the phosphorus (P) fertilizer application or the inherent variation of root system development of the various cowpea genotypes. Cowpea varieties that received $30 \mathrm{~kg}$ $\mathrm{ha}^{-1}$ of $\mathrm{P}$ fertilizer produced relatively higher quantities of root dry biomass as compared to the genotypes which did not receive $\mathrm{P}$ fertilizer. A study conducted by Sharma and Paliwal (1973) revealed that phosphorus application increased root biomass yield and increased grain yield of succeeding crops.

\section{Nodule Dry Biomass Production}

The level of phosphorus (P) fertilizer application significantly $(\mathrm{p}<0.05)$ influenced the number of nodules formed per plant among the varieties. The varieties Valenga and DPC produced relatively higher number of nodules per plant at $\mathrm{P}$ level of $30 \mathrm{~kg} \mathrm{ha}^{-1}$ as compared to $\mathrm{P}$ level of $0 \mathrm{~kg} \mathrm{ha}{ }^{-1}$. The significant variation in nodulation among varieties could be attributed to difference in the genetic makeup of the individual varieties as reported by (Ayodele and Oso, 2014). Sharma and Paliwal (1973) observed that heavy dose of $\mathrm{P}\left(111 \mathrm{~kg} \mathrm{ha}^{-1} \mathrm{P}_{2} \mathrm{O}_{5}\right)$ produced a significant increase in both nodule number and nodule weight per plant when they studied the effect of phosphorus and Molybdenum fertilization on the nodulation of cowpea.

The production of nodule dry biomass significantly varied among genotypes at both phosphorus (P) application levels and this might probably be due to variation in the ability of individual genotypes to utilize P. The result of the nodule dry biomass yield in this study compares favorably with the observation made by Nkaa et al. (2014) who stated that increasing P levels result in corresponding increases in the number and size of nodules. They further reported that phosphorus initiates nodule formation as well as influence the efficiency of the rhizobium-legume symbiosis, thereby enhancing nitrogen fixation. Singh et al. (2011) also reported that $\mathrm{P}$ application increased the number of branches, dry weight of shoots and nodules per plant but other characters remained unaffected.

\section{Conclusion and Recommendations}

The experiments were conducted during the 2014 and 2015 cropping seasons to examine the effect of phosphorus (P) fertilizer application and row spacing on nodulation and biomass yield of four cowpea cultivars.

The study revealed that, cowpea varieties DPC and Valenga performed relatively better with respect to shoot and root dry biomass yield, number of nodules produced and nodule dry biomass yield across both levels of row spacing and phosphorus $(\mathrm{P})$ fertilizer application.

The study further established that row spacing of $60 \times 40 \mathrm{~cm}$ and $\mathrm{P}$ level of $30 \mathrm{~kg} \mathrm{ha}^{-1}$ also produced significantly higher quantities of shoot and root dry biomass yield, number of nodules produced and nodule dry biomass yield as compared to row spacing of $40 \times 20$ $\mathrm{cm}$ and $\mathrm{P}$ level of $0 \mathrm{~kg} \mathrm{ha}^{-1}$.

For the purpose of producing leguminous fodder crops for feeding livestock, it is recommended that:

Varieties DPC and Valenga should be cultivated for improved animal nutrition.

Row spacing of $60 \times 40 \mathrm{~cm}$ and phosphorus fertilizer application level of $30 \mathrm{~kg} \mathrm{ha}^{-1}$ should also be used for increased biomass yield.

\section{Acknowledgement}

We do acknowledge the critical comments and scientific inputs made by all researchers of the Department of Agronomy, University for Development Studies, Tamale, as well as the CSIR - Savanna Agricultural Research Institute, Nyankpala.

\section{Author's Contribution}

Alhassan Bawa: Participated in the development of the concept of the experiment, designed the research, data analysis, interpretation of analysed data and the entire process of the article preparation.

Lukman Yussif: Participated in the development of the concept of the experiment, field preparation, data collection, data organization and proof reading of the prepared article.

\section{Competing Interest}

Authors have declared that no competing interests exist.

\section{References}

Acquaye, D.K., 1968. Nitrogen transformation in soils under cocoa. Rep. Cocoa Res. Inst., Ghana.

Ahenkorah, Y., 1967. Phosphorus-retention capacities of some cocoa-growing soils of Ghana and their relationship with soil properties. Soil Sci., 105: 24-30. DOI: 10.1097/00010694-196801000-00006

Ayodele, O.J. and A.A. Oso, 2014. Cowpea responses to phosphorus fertilizer application at Ado-Ekiti, SouthWest Nigeria. J. Applied Sci. Agric., 9: 485-489.

CRI, 2006. Crops Research Institute (CRI) of Ghana. Annual Report.

Fageria, N.K., A.B. Dos Santos, V. Cutrim and A. Dos, 1997. Growth and Mineral Nutrition of Field Crops. 2nd Edn., Marcel Dekker, New York, ISBN-10: 0824700899, pp: 640. 
Haruna, I.M. and L. Aliyu, 2011. Yield and economic returns of sesame (Sesamum indicum L.) as influenced by poultry manure, nitrogen and phosphorus at Samaru, Nigeria. Elixir Agric., 39: 4884-4887.

IITA, 2003. Crop and farming systems. International Institute of Tropical Agriculture, Ibadan, Oyo State, Nigeria.

Magani, I.E. and C. Kuchinda, 2009. Effect of phosphorus fertilizer on growth, yield and crude protein content of cowpea (Vigna unguiculata [L.] Walp) in Nigeria. J. Applied Biosci., 23: 1387-1393.

Mokwunye, A.U. and A. Bationo, 2002. Meeting the Phosphorus Needs of Soils and Crops of West Africa: The Role of Indigenous Phosphate Rocks. In: Integrated Plant Nutrient Management in Sub-Saharan Africa: From Concept to Practice, Vanlauwe, B., J. Diels, N. Sanginga and R. Merckx (Eds.), CABI, Oxon, UK., ISBN-13: 9780851998855 , pp: 209-224.

Ndakidemi, P.A. and F.D. Dakora, 2007. Yield components of nodulated cowpea (Vigna unguiculata) and maize (Zea mays) plants grown with exogenous phosphorus in different cropping systems. Aust. J. Exp. Agric., 47: 583-589. DOI: 10.1071/EA05274

Nkaa, F.A., O.W. Nwokeocha and O. Ihuoma, 2014. Effect of phosphorus fertilizer on growth and yield of cowpea (Vigna unguiculata). IOSR J. Pharm. Biol. Sci., 9: 74-82.

Osodeke, V.E., 2005. Determination of phosphorus requirements of Cowpea (Vigna unguiculata) in the acid soils of South-Eastern Nigeria using sorption isotherms. Global J. Agric. Sci., 4: 135-138.

DOI: 10.4314 /gjass.v4i2.2262
Oti, N.N., B.U. Uzoho and C.C. Opara, 2004. Determination of phosphorus requirement of cowpea using P-sorption isotherm. Int. J. Agric. Rural Dev., 5: 77-85. DOI: 10.4314/ijard.v5i1.2566

Rowland, J.R.J., 1993. Legume Crops. In: Dry Land Farming in Africa, Rowland, J.R.J. (Ed.). Macmillan Education Ltd., London and Basingstoke. Published in co-operation with the Technical Centre for Agricultural and Rural Co-operation (CTA). pp: 336.

Sanginga, N., O. Lyasse and B.B. Singh, 2000. Phosphorus use efficiency and nitrogen balance of cowpea breeding lines in a low $\mathrm{P}$ soil of the derived savanna zone in West Africa. Plant Soil, 220: 119-128. DOI: $10.1023 / \mathrm{A}: 1004785720047$

Sharma, S.C., A.K. Vyas and M.S. Shaktawat, 2002. Effect of levels and sources of phosphorus under the influence of farm yard manure on growth determinants and productivity of soybean [Glycine $\max$ (L.) Merrill]. Indian J. Agric. Res., 36: 123-127.

Sharma, V.V. and P.C. Paliwal, 1973. Evaluation of cane final molasses in layer rations. Indian J. Anim. Sci., 43: 325-329.

Singh, A., A.L. Baoule, H.G. Ahmed, A.U. Dikko and U. Aliyu, 2011. Influence of phosphorus on the performance of cowpea (Vigna unguiculata (L.) Walp.) varieties in the Sudan savanna of Nigeria. Agric. Sci., 2: 313-317. DOI: 10.4236/as.2011.23042 